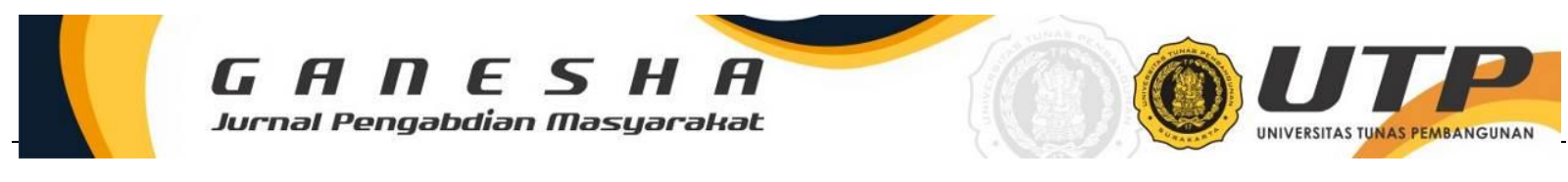

\title{
DIVERSIFIKASI PRODUK OLAHAN PANGAN LOKAL BERBASIS KOMODITAS WORTEL
}

\author{
Ratih Dwi Kartikasari*1, Dwi Susilo U. ${ }^{2}$, Tyas Soemarah K.D. ${ }^{3}$, Haryuni ${ }^{4}$, Wiyono ${ }^{5}$ \\ 1,2,3,4,5 Universitas Tunas Pembangunan Surakarta \\ Email Korespondensi: ratihkartika14@gmail.com
}

\begin{abstract}
Abstrak
Permintaan produk olahan pangan yang sehat dan bernutrisi semakin lama semakin bertambah seiring dengan peningkatan kesadaran masyarakat akan pola hidup sehat. Wortel sebagai salah satu komoditas pertanian memiliki kandungan gizi baik yang dapat diolah menjadi berbagai pangan olahan. Selain meningkatkan kreativitas, pengolahan pangan berbasis wortel dapat membantu petani meminimalisir kerugian akibat harga yang anjlok ketika panen raya. Tujuan dari kegiatan pendampingan ini adalah peningkatan partisipasi masyarakat Desa Berjo, Kecamatan Ngargoyoso, Kabupaten Karanganyar melalui pendampingan dan pelatihan. Metode yang digunakan adalah metode pendekatan, sosialisasi, dan pelatihan pengolahan produk pertanian. Hasil kegiatan menunjukkan bahwa masyarakat yang berpartisipasi tidak kesulitan dalam melakukan pengolahan produk mie dan nugget wortel. Produk yang dihasilkan dari kegiatan ini berupa inovasi baru mie dan nugget wortel yang mempunyai nilai tambah ekonomi sehingga secara kontinyu dapat menambah pendapatan rumah tangga masyarakat Desa Berjo.
\end{abstract}

Kata kunci: diversifikasi, pangan sehat, pelatihan, wortel.

\begin{abstract}
The demand for processed food products that are healthy and nutritious is increasing over time along with the increase in public awareness of healthy lifestyles. Carrots as an agricultural commodity have good nutritional content that can be processed into various processed foods. In addition to increasing creativity, carrot-based food processing can help farmers minimize losses due to falling prices during major harvest. The purpose of this mentoring activity is to increase community participation in Berjo Village, Ngargoyoso District, Karanganyar Regency through mentoring and training. The method used is the method of approach, socialization, and agricultural product processing training. The results of the activity showed that the participating communities had no difficulty in processing noodle products and carrot nuggets. The products produced from this activity are in the form of new innovations of noodles and carrot nuggets which have added economic value so that they can continuously increase the household income of the people of Berjo Village.
\end{abstract}

Keywords: carrots, diversification, healthy food, training.

\section{PENDAHULUAN}

Sektor pertanian Indonesia memiliki peranan yang cukup besar terhadap perekonomian nasional. Pembangunan pertanian di Indonesia ditujukan untuk meningkatkan produksi guna memenuhi kebutuhan pangan dalam negeri, meningkatkan ekspor, memperluas lapangan pekerjaan, mendorong kesempatan berusaha serta meningkatkan pendapatan dan kesejahteraan petani. Strategi pengembangan pertanian ditujukan pada pembangunan sistem dan usaha agribisnis yang berdaya saing, berkelanjutan dan teresentralisasi (Soekartawi, 2003).

Permintaan produk olahan pangan yang sehat dan bernutrisi semakin lama semakin bertambah seiring dengan peningkatan kesadaran masyarakat akan pola hidup sehat. Salah satu upaya peningkatan produksi untuk memenuhi permintaan yang meningkat adalah dengan pemanfaatan pekarangan. Pemanfaatan tanaman pekarangan dapat dijadikan lahan usaha tani yang efektif untuk mendukung program peningkatan produksi dan ketahanan pangan keluarga di perkotaan maupun pedesaan (Mardiyanto, 2009).

Salah satu daerah yang menerapkan pemanfaatan pekarangan adalah Desa Berjo, Kecamatan Ngargoyoso, Kabupaten Karanganyar. Lahan yang masih luas serta cuaca yang mendukung mendorong masyarakat untuk aktif bertani khuusnya tanaman hortikultura. Salah satu produk unggulan yang diproduksi adalah tanaman wortel. Pemanfaatan lahan pekarangan sebagai media tanam sayuran dapat menambah penghasilan masyarakat apabila dihasilkan 
dan diolah menjadi produk pangan yang bernilai ekonomis (Amelia, et al. 2019). Produksi yang besar pada saat panen dan belum terserap pasar menjadi permasalahan yang dijumpai masayarakat. Salah satu cara yang dapat dikembangkan untuk peningkatan kesejahteraan masyarakat adalah dengan pemanfaatan potensi lokal secara optimal. Marsigit (2010) mengatakan bahwa pembangunan perlu diarahkan kepada pemanfaatan potensi sumberdaya lokal baik alam maupun manusianya. Peningkatan ketahanan pangan harus didasarkan pada penggalangan kekuatan sumberdaya lokal dan sekecil mungkin tergantung input dari luar (impor).

Peningkatan nilai tambah produk hasil pertanian dengan pengolahan akan menjadi salah satu solusi penanganan produk yang tidak terserap pasar khususnya ketika panen raya. Secara umum yang menjadi tujuan dan sasaran yang ingin dicapai dalam kegiatan pengabdian masyarakat bagi mitra dan masyarakat adalah peningkatan partisipasi khalayak sasaran di Desa Berjo, Kecamatan Ngargoyoso, Kabupaten Karanganyar melalui pelatihan dan pendampingan pengolahan produk pertanian lokal. Tujuan khusus dari pengabdian yang dilakukan adalah meningkatkan kemampuan pengolahan produk lokal untuk memperoleh nilai lebih sehingga meningkatkan kesejahteraan masyarakat.

\section{METODE}

Lokasi pengabdian di lakukan di Desa Berjo, Kecamatan Ngargoyoso, Kabupaten Karanganyar pada 20 Juni 2020. Peserta dari kegiatan pengabdian adalah masyarakat Desa Berjo khususnya ibu-ibu PKK sejumlah 15 orang dengan menerapkan protokol kesehatan dalam suasana covid-19. Metode yang digunakan adalah sosialisasi dan pelatihan terhadap peserta.kegiatan dimulai dengan diskusi terkait komoditas potensial di Desa Berjo serta pengetahuan partisipan terkait pengolahan produk unggulan, di dalam penelitian ini adalah sayur wortel. Setelah diskusi berlangsung, peserta diberi sosialisasi terkait pentingnya melakukan pegolahan produk dan diversifikasinya dan dilaknjutkan dengan kegiatan pelatihan pengolahan. Metode pengambilan dan pengumpulan data yang digunakan dalam kegiatan ini adalah metode deskriptif. Data yang terkumpul diolah dan dianalisis secara kualitatif.

\section{HASIL DAN PEMBAHASAN}

Diversifikasi produk olahan pangan berbasis komoditas lokal telah dilaksanakan di Desa Berjo, Kecamatan Ngargoyoso, Kabupaten Karanganyar. Kegiatan yang telah dilaksanakan adalah koordinasi, sosialisasi masyarakat, pelatihan dan pendampingan.

\section{Koordinasi}

Kegiatan pertama yang dilakukan berupa koordinasi dengan kepala Desa terkait sasaran (masyarakat setempat). Hasil koordinasi melalui media elektronik adalah masyarakat sasaran bersedia mendukung dan berkontribusi langsung dalam kegiatan pengabdian di Desa Berjo Kecamatan Ngargoyoso, Kabupaten Karanganyar. Ibu-ibu PKK juga bersedia berpartisipasi aktif dalam program pelatihan pengolahan pangan berbasis komoditi lokal yaitu sayur wortel.

\section{Sosiaslisasi masyarakat}

Kegiatan kedua adalah sosialisasi masyarakat tentang motivasi sebagai seorang wirausaha, teknik pengolahan produk pertanian, serta pelatihan pengolahan produk pertanian menjadi mie dan nugget. Hasil koordinasi dan sosialisasi pendampingan ini adalah meningkatnya motivasi kewirausahaan masyarakat Desa Berjo dengan meningkatkan pendapatan keluarga sehingga dapat mengurangi pengangguran.

\section{Pelatihan Pengolahan Produk Pertanian}

Kegiatan selanjutnya adalah pelatihan dan pendampingan pengolahan produk pertanian wortel menjadi mie homamade dan nugget sehat. Pelatihan ini bermanfaat untuk mengenalkan 
potensi lokal yang belum banyak dilakukan diversifikasi produk untuk meningkatkan nilai tambah produk.

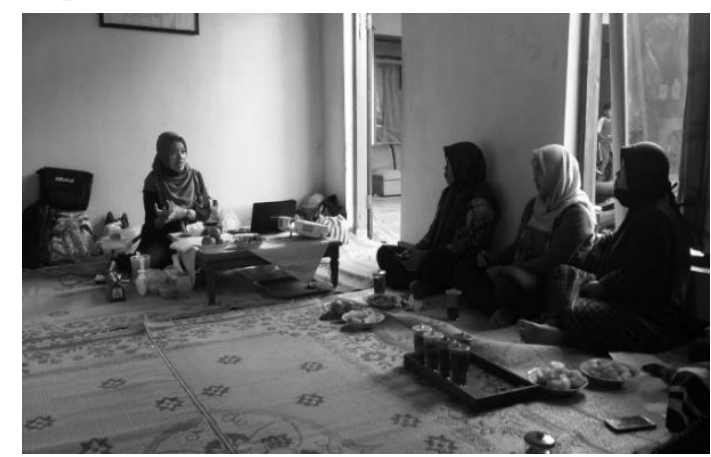

Gambar 1. Persiapan kegiatan

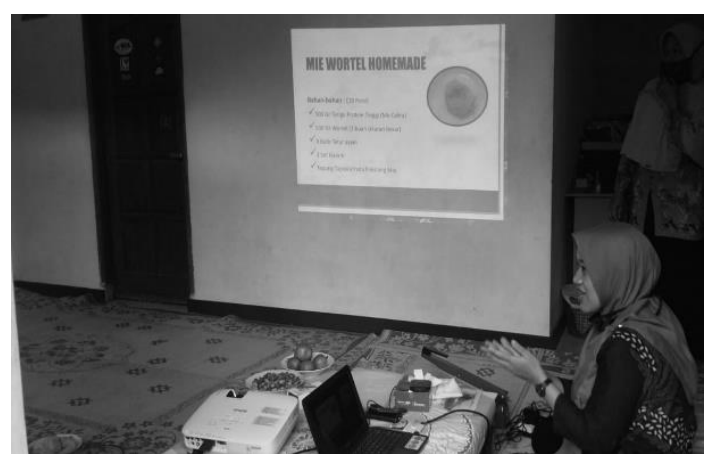

Gambar 2. Penyampaian materi sosialisasi

Wortel merupakan salah satu komoditas yang dihasilkan petani di Desa Berjo dan panen setiap 3 bulan sekali. Hingga saat ini, permintaan wortel cukup tinggi di wilayah lokal Tawangmangu dan sekitarnya. Permasalahan yang kerap terjadi adalah ketika panen raya produksi yang tinggi belum dibarengi dengan terserapnya pasar secara optimal sehingga mengakibatkan harga wortel tidak dapat bersaing. Pengolahan produk mentah menjadi produk setengah jadi ataupun produk jadi dapat membantu masyarakat keluar ari masalah kerugian saat panen raya.

Marsigit (2010) menyatakan bahwa sebaran produk pangan olahan sangat terkait erat dengan potensi ketersediaan bahan baku utama (pangan lokal). Bahan baku utama adalah bahan pembuatan produk olahan berasal minimal 25\% dari produk pertanian, sesuai dengan salah satu pengertian agroindustri menurut Soekartawi (2003).

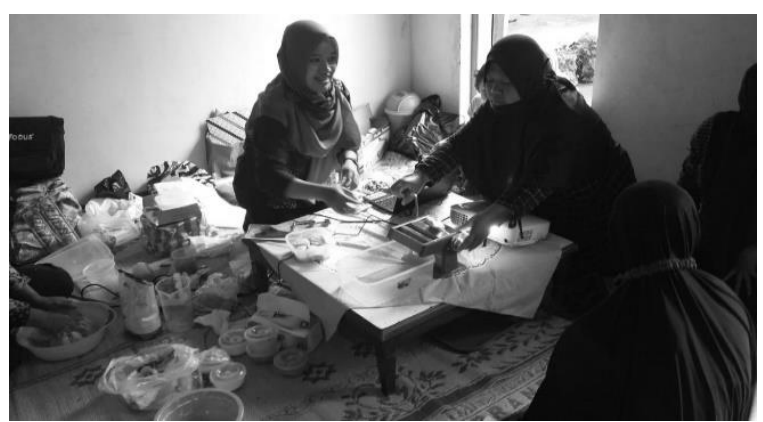

Gambar 3. Pelatihan bersama partisipan

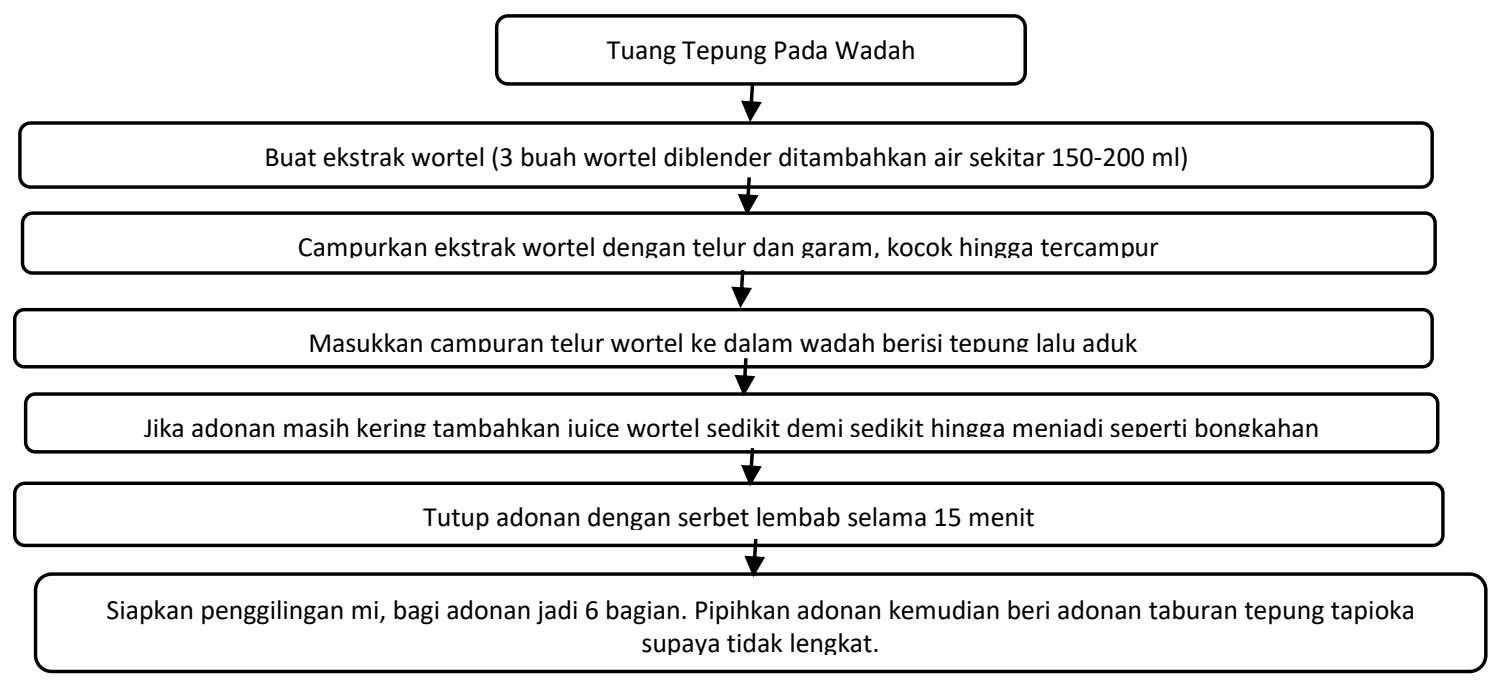

Gambar 4. Alur pembuatan mie wortel 
Wortel memiliki banyak kandungan vitamin yang dibutuhkan oleh tubuh diantaranya adalah zat Makronutrien yang berupa Air : 89.9 g, Energi : $36 \mathrm{Kal}$, Protein : $1.0 \mathrm{~g}$, Lemak : 0.6 g, Karbohidrat : 7.9 g, Serat : $1.0 \mathrm{~g}$; zat Mineral berupa Kalsium : $45 \mathrm{mg}$, Fosfor : $74 \mathrm{mg}$, Zat Besi: 1,0 mg, Sodium : $70 \mathrm{mg}$, Kalium : 245,0 mg, Tembaga : 0,06 mg, Seng : 0,3 mg, serta zat Vitamin dan antioksidan yang berupa Beta-Karoten : 3,784 mcg, Karoten : 7.125 mcg, Thiamin : 0,04 mg, Riboflavin : 0,04 mg, Niasin : 1,0 mg, Vitamin C : $18 \mathrm{mg}$. (Kemenkes, 2017). Produk mie olahan dan nugget sehat menjadi alternatif makanan ataupun cemilan sehat keluarga. Pengolahan yang tidak rumit serta bahan baku yang mudah didapat menjadi keuntungan bagi peserta untuk dapat mengembangkan usaha menjadi lebih terstruktur dan terkonsep.

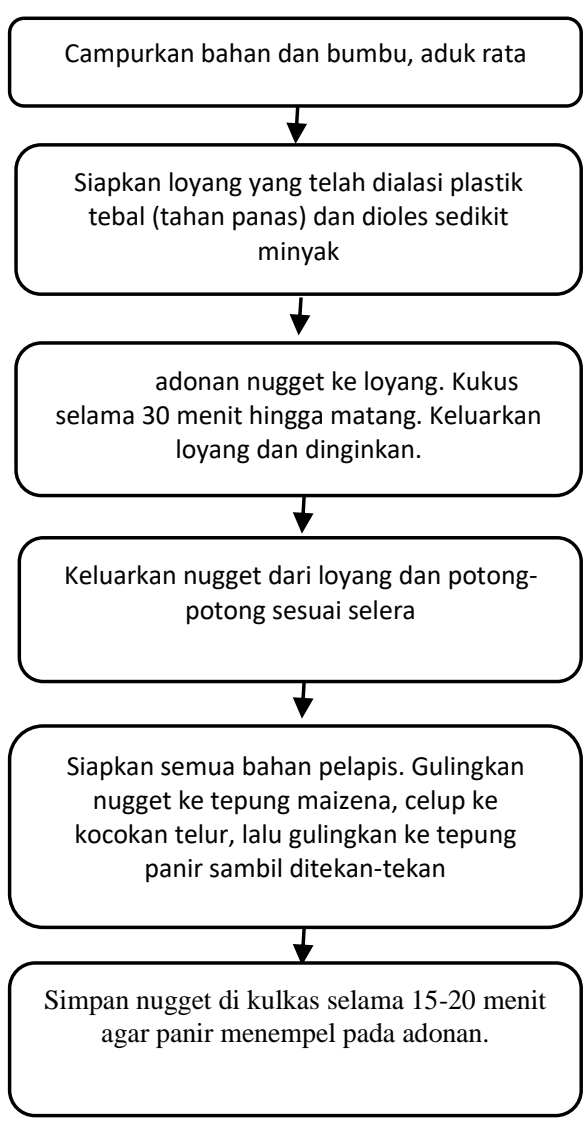

Gambar 5. Alur pembuatan nuugget wortel

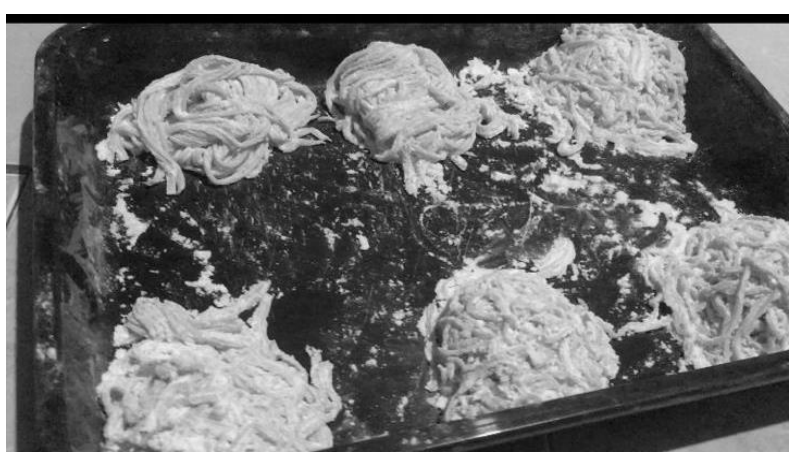

Gambar 6. Hasil Mie Wortel 
Kegiatan pengolahan produk berbasis komoditas wortel bertujuan untuk meningkatkan pengetahuan, wawasan, dan ketrampilan peserta tentang pengolahan pangan terutama yang beragam, bergizi, sehat, serta bernilai ekonomis. Manfaat dari kegiatan pelatihan dan pendampingan yang telah diajarkan adalah : 1) memberi tambahan informasi, pengetahuan, wawasan, serta ketrampilan kepada peserta, 2) produk olahan bernilai ekonomis dan dapat menjadi sumber pendapatan rumah tangga sehingga meningkatkan kesejahteraan.

Produk olahan pangan dapat dikomersilkan dengan teknik pemasaran yang tepat, salh satunya dengan teknik pemasaran secara online. Hal ini didukung oleh masyarakat yang didominasi usia produktif dan sudah mengenal media internet seperti instagram, facebook, whatsap, ataupun media lain. Teknik pemasaran secara online lebih mudak dilaksanakan karena fleksibel dari segi waktu, tidak membutuhkan modal besar sehingga dapat dilakukan oleh kalangan manapun serta jangkauan pemasaran akan lebih luas. Konsumen akan lebih mudah melihat dan memilih produk secara online karena lebih efisien waktu dan tenaga. Pada dasarnya konsumen selalu menginginkan kemudahan bila ingin membeli suatu produk (Wandanaya, 2012).

\section{KESIMPULAN}

Permasalahan pasca panen produk wortel yang belum optimal diserap pasar dapat diminimalisir dengan memberikan perlakuan tambahan yaitu pengolahan produk. Pelatihan dan pendampingan ini bermanfaat untuk meningkatkan wawasan tentang wirausaha, informasi pengolahan produk khususnya pangan yang beragam, bergizi, sehat, dan bernilai ekonomis. Produk olahan yang dihasilkan selain dikonsumsi sendiri dapat dipasarkan dengan berbagai teknik diantaranya adalah teknik pemasaran online.

\section{UCAPAN TERIMA KASIH}

Terimakasih kepada Bapak Mulyanto selaku mitra kegiatan Pengabdian pada Masyarakat Desa Berjo, Kecamatan Ngargoyoso, Kabupaten Karanganyar yang telah mengikuti kegiatan pengabdian masyarakat. Terimakasih kepada segenap pihak-pihak yang telah membantu dalam proses kegiatan pengabdian pada masyarakat ini.

\section{DAFTAR PUSTAKA}

Amelia, J.R., Mulyawati, I., \& Ratnasari, L. (2019). Diversifikasi Produk Olahan Pangan Hasil Aplikasi Vertikultur Tanaman Sayuran di Kelurahan Tengah, Kramat Jati, Jakarta Timur. Jurnal Agrokreatif. vOl. 5. Np. 3 pp: 216-225.

Kementrian Kesehatan Republik Indonesia. (2017). http://www.p2ptm.kemkes.go.id/artikelsehat/buah-dan-sayur-pelindung-mata-ini-daftarnya

Mardiyanto A. (2009). Perencanaan Lanskap Pekarangan Dengan Sistem Pertanian Terpadu. [Skripsi]. Bogor (ID): Institut Pertanian Bogor.

Marsigit, W. (2010). Pengembangan Diversifikasi Produk Pangan Olahan Lokal Bengkulu untuk Menunjang Ketahanan Pangan Berkelanjutan. Jurnal Agritech. Vol. 30. No. 4 pp: 256-264.

Soekartawi. (2003). Agribisnis Teori Dan Aplikasinya. PT Raja Grafindo Persada. Jakarta

Wandanaya, A.B. (2012). Pengaruh Pemasaran Online Terhadap Keputusan Pembelian Produk. CCIT Journal. Vol. 5 No. 2 pp: 174-185. 